\title{
University Governance in the Context of Vietnam's Educational Innovation
}

\author{
Lan Chi Le ${ }^{+}$, \\ Dang Ton Minh Co, \\ Thai Dinh Do
}

\section{Article history}

Received: 17 September 2021

Accepted: 30 November 2021

Published: 29 December 2021

\section{Keywords}

University governance, strategic planning, education innovation, Vietnam

\author{
Saigon University, Vietnam \\ +Corresponding author•Email: lechilan@sgu.edu.vn
}

\section{INTRODUCTION}

In the present context of globalization and fierce international competition, Vietnam's higher education system must carry out an appropriate management innovation. Despite its day-to-day development, Vietnamese higher education is, in fact, still behind many countries in the region. While progressive universities have been employing university governance policies, most of Vietnamese ones are still using activity management models with the aim of making use of and combining their resources so as to achieve their goals, which cannot satisfy the requirements of innovation in the context of globalization and integration. In reality, the current Vietnamese university management model consists of a university board or management board along with the Board of Administrators and all decisions on management activities are made by the Director Board. The majority of training institutions in Vietnam have built neither appropriate management mechanisms, nor concrete hierarchy, nor independent monitoring mechanism among the composing parts. Most of the colleges and universities' directors achieve their management positions and leadership by implementing circulars, decisions, resolutions issued by their superiors, which clearly affects the operation, management and governance of the school (Le \& Do, 2019).

University governance is a notion relatively new to Vietnam, referring to the process of organizing, operating and controlling the activities of a university in order to achieve the best possible educational and training objectives. It is no difference from gathering and developing operational rules and quality assurance systems in universities. In the context of ever-changing social development and the era of the knowledge economy, with the trend of profound integration and internationalization in all fields, especially education, it is essential for universities to research on effective university governance methods. It is the underlying reasons for this study, which also aims to propose a system to access university governance methods in our contemporary global situation.

VES Conference 2021 was jointly organized by AVSE Global, University of Social Sciences and Humanities, Ho Chi Minh City and Viet Nam Journal of Education to review the efforts to adapt and reform the higher education system that have gradually furthered the process of redefining research, teaching and learning activities, reperceiving 
and ensuring quality in higher education. Meanwhile, new thinking in leadership and management has led to tremendous changes, helping to reshape higher education. One of the topics of the Conference is related to Higher Education Governance and Management. Therefore, the purpose of this article is to study and propose university governance in the context of Vietnam's educational innovation in the direction of a systems approach. For the mentioned purpose, the article aims to fulfill the following specific tasks: Examining some educational innovation policies; reviewing by systemic approach; interpreting concepts related to university governance. Accordingly, the authors consulted a number of educational experts on the proposed model of university governance towards the systemic approach. Subsequently, they collected feedbacks on the proposed model and recommended some implications the implementation of university governance.

\section{LITERATURE REVIEW}

\subsection{Some policies on educational innovation}

According to Resolution 14/2005/NQ-CP dated 02/11/2005 on the fundamental and comprehensive educational innovation in the period 2006-2020, the Prime Minister stated, "we must consider university education management innovation including both of the government management and educational institutions' management as the breakthrough to create a comprehensive reform of higher education, thereby ensuring and improving the training quality and efficiency in a sustainable way”. So, facing globalization and international competition, Vietnamese higher education must innovate its management to meet up with the actual situation. Moreover, Vietnam has entered a new phase of development and integration. Modern industrialization has been identified as the core of the national development strategy. Our Communist Party and State have always asserted that: Education and training, science and technology are the leading ones in the list of direction and strategies for national construction and development policies. The eighth conference of the Central Executive Committee of the Party adopted Resolution No.29-NQ/TW on the fundamental and comprehensive educational innovation to meet the requirements of industrialization and modernization in the conditions of socialist-oriented market economy and international integration. Our Party has clearly stated that the primary goal of educational innovation is: "Education must swiftly shift from mainly equipping knowledge to comprehensively developing learners' capabilities and qualities. Learning in connection with practice; theory associated with facts; school education combined with family and society".

In 2017, the Prime Minister issued Directive No.16/CT-TTg on promoting access to the Industrial Revolution 4.0. In 2019, the Political Committee issued Resolution No.52-NQ/TW on a number of policies to actively participate in the Industrial Revolution 4.0, seting out a number of guidelines, basic and crucial policies with many practical solutions, requiring robust innovation, supplementation and improvement of educational policies, contents and methods in order to develop human resources capable of handling new production technology trends.

For education and training, what has to be done in this context is to equip the workforce with knowledge and capacities to master new and advanced technologies. The education sector requires visions to deal with constantly shifting organizational forms and skills requirements. Accordingly, managers need to have appropriate management methods to adapt to changes in the current educational innovation context.

\subsection{Systemic Approach}

System refers to a set of different components, among which there is a certain relationship and interaction according to a certain rule to form a whole, capable of performing certain specific functions. When it comes to education management approach, it is necessary to pay attention to the system which is a set of components together with their interactions, including components such as: inputs (raw materials, fuels, materials, resources); transformation process (management process and technology); outputs (products and services) and feedbacks (environmental responses). The basic principle of system theory is that every system consists of small systems called subsystems, among which there is an organic influencing relationship, every change, even tiny ones, affects the system and vice versa (Do Tien Vuong, 2014).

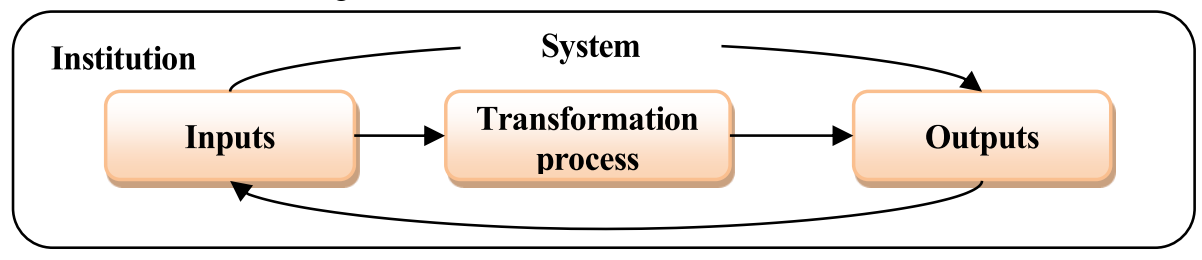

Figure 1. System diagram in an educational institution (Do, 2014) 
A system in a university is a set of components that the university uses to accomplish its goals, including resources; controlling principles; controlling process; controlling mechanism; controlling method and operational properties. Activities in the university constitute a system complying with the principle of mutual interactions and interactions with the environment. They can gain new attributes which can be seen through new phenomena as a result of development and progress.

\subsection{University Governance}

University governance is an approach in which authorities lead and monitor the goals and values of the university through policies and implementation procedures (Allan, 2012).

In another way, university governance is composed of a process of constructing a set of rules and systems to manage and control all activities of a university. Its governors take responsibility to the university, community and students for the reliability, adaptability, management efficiency through the division of responsibilities, resources and control of effectiveness (Nguyen \& Nguyen, 2013).

Governance is the process of planning, organizing, leading and controlling the activities of the members of the organization and using all other resources of the organization to achieve the proposed goals (Kezar \& Eckel, 2004). Education institution's resources include:

- Workforce: Staff of lecturers, officers, and employees with their professional competencies participate in the university's activities. Human resources are the most important resource, the most precious capital for the institution's development. Gathering them and creating opportunities for all of them to promote their full potential for the institution's activities is to mobilize the greatest resources for the development of the institution (Do, 2015).

- Financial resources: From the perspective of different operating mechanisms, financial resources for activities in educational institutions include: State budget comprises all estimated revenues and expenses which are assigned by the Government to perform functions and tasks of an institution. Other financial resources than the State budget are all elements of financial capital that the State allows institutions to mobilize directly as socialization capital in order to ensure financial resources for institutions and are used according to the prescribed regime to achieve institutions' goals (Tran, 2018).

- Material resources: All physical facilities with all physical ways are used to accomplish the institution's goals, such as: lands, properties, equipment, tools (tangible) and softwares, patents, inventions, reputation, prestige (invisible) of the university. Facilities determine labor productivity and efficiency of university activities.

- Information resources: All data have been analyzed and processed to help with decision making or task settling for institutional development. Scientifically organized information systems change the way in which institutions operate, make institutions' structure simpler, more flexible, and help to find the necessary information in a short amount of time and at a reasonable cost. Information is both an indispensable input and a potential reserve for any institution.

Ngo (2012) said that: "University governance is approached and perceived from many different angles, particularly, its management forms the destiny of a university. An appropriate university governance is the heart which determines success or failure of any university". In the current development environment, university governance is considered and examined from different points of view. These problems are multi-dimensionally approached and appeal to more and more attention. This can be seen through the number of policy systems of university governance which are increasing and realistically inclined to realize resolutions, decrees and decisions of the Prime Minister and relevant Ministries.

To sum up, in this study, the authors refer to the term of university governance as the process of organizing, operating, checking and monitoring the activities of the university in order to achieve the educational and training goals in the most optimal way. Therefore, university governance in this article also refers to planning resource development; policy mechanism; organizing; leading and monitoring in the university.

(1) Planning resource development strategies in the university (aka HD)

Strategic planning is an organization's governing function that comprises setting priorities, centralizing resources, and consolidating operational activities to ensure that the organization's employees and other stakeholders could work harmoniously for shared objectives, achieving consensus on expected outcomes, evaluating and adjusting the direction of organizational operations to deal with the changing educational environment (Cao, 2016).

Planning the development strategy in the university includes planning and organizing the implementation of the university development strategies related to areas such as program development, teaching plans; university enrollment etc.; revenues from training activities at all levels, scientific research and strategies for developing teaching staff (Le, 2021).

(2) Policy mechanism governance (aka CC) 
Mechanism means a socio-economic organizational structure such as: The structure between the substructure and superstructure. Policies are political strategies that are consistent with the socio-economic characteristics and conditions of each development stage and aimed at ensuring the appropriate and positive operation of the mechanism. As being mentioned, policies must include a basic policy and a "responsive" policy. Basic policies are long-term (strategic) policies such as: long-term policies, medium-term policies and policies that are "responsive" to emerging characteristics, to a certain extent, called "strategy" (Nguyen \& Nguyen, 2015).

The operating model of universities is currently inclined to the management function. The governance of policy covers 4 specific contents: separating governing activities from management activities; developing a mechanism to ensure that the University Council is the highest authority in the university; associating the activities of the University Council with the exercise of autonomy and social responsibility of the university; and determining the content, form, accountability mechanism and evaluating the level of accountability of the university (Dinh, 2019).

(3) Organizing resource development (aka TC)

Organizing, operating and controlling the activities of the university aim at achieving the educational and training goals in the most optimal way. The organization of resource development at the university targets at decentralizing and exercising authority at the university (Simon et al., 2000).

Organizing resource development in the university plays an important role as the resources of the university need governing well when there is a specific assignment and exercise of power. Resource development organizations include Party Committee, University Council and Management Board; It is necessary to clearly define the tasks and powers of the units and organizations in the university, and build a coordination mechanism between the Party Committee, the University Council, the Management Board and other units and organizations in the university (Nguyen \& Nguyen, 2013). Organizing resource development is expected to restructure the management apparatus in a streamlined, professional manner and delegate authority to departments, collegiate institutes, etc.

(4) Orienting resource development (aka LD)

Orienting resource development is the process of exploiting and coordinating the activities of individuals in an organization by influencing and directing the behavior of individuals or groups of people towards organizational goals. Leadership is one of the most important concepts in organizational science - human resources (Le, 2019).

Orienting resource development requires proper resource leadership and an effective support system etc. This concept also consists of motivating everyone to realize the school's development goals and strategies, building a strict and feasible legal framework binding the self-responsibility of the university's head, researching to improve the organizational system of quality teaching and learning of both teachers and students (Allan, 2012).

(5) Checking and monitoring activities (Abbrev. KT)

Checking and evaluating activities at higher education institutions are activities to help detect loopholes in the management mechanism, derogations and violations of the law, and recommend remedial measures to prevent and assist units, organizations and individuals in the university perform their functions (Le, 2021).

Checking and monitoring play an important part in university governance by ensuring the balance, appropriateness and harmony between enrollment and the social needs of the educational program innovation; it is also believed to maintain the checking and monitoring of the economic conditions of the university based on studying the effectiveness of investment in education (Pham, 2009).

In brief, the authors propose 5 components related to university governance, including: (1) Planning resource development in the university; (2) Policy mechanism governance; (3) Organizing resource development; (4) Orienting resource development; (5) Checking and monitoring activities through system governance concerning inputs, processes and outputs.

\section{MATERIALS AND METHODS}

- The objective of the survey is to properly and objectively assess the situation of university activities management to establish the empirical framework of the study.

- The survey focuses on the 5 main contents namely: (1) Planning resource development; (2) Governance of policy

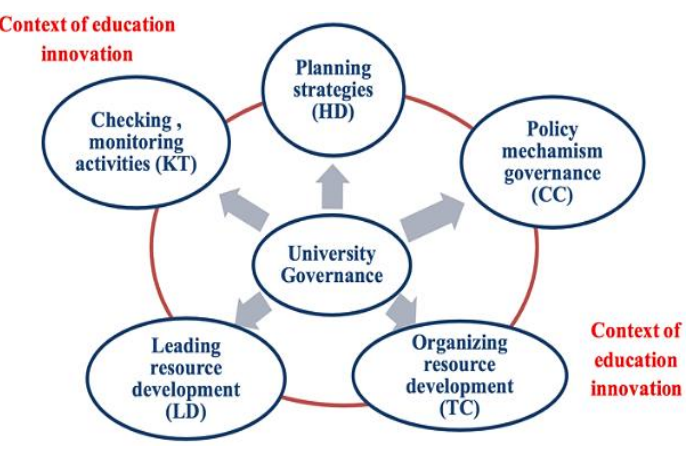

Figure 2. Diagram of the elements of university governance in the context of education innovation (Kezar \& Eckel, 2004) 
mechanisms; (3) Organizing resource development; (4) Orienting resource development; (5) Checking and monitoring activities.

- Samples and survey subjects: Samples are 120 management officers and lecturers of Saigon University. Sampling was carried out in each department to select a quarter of its staff using the list provided by the personnel department.

- The survey is conducted following these steps: (1) Discussing with surveyed subjects and experts to form the survey questionnaire; (2) Designing the first version of the survey; (3) Consulting experts' opinion and piloting it on a small sample; (4) Revising the first version of the survey questionnaire and finalising to create the official second; (5) Selecting the survey samples; (6) Collecting responses through the survey questionnaire and discussing with the surveyed subjects about the issues that need studying collectively but have not been mentioned in the questionnaire; (7) Processing information from the survey samples by mathematically statistical method.

- Samples and interviewees: 10 management officers.

- Use SPSS version 22.0 for processing the data obtained from the survey questionnaires.

- Rating scale: from level 1 to level 5 from "totally disagree to strongly agree".

The average score is divided into 5 levels: Distance value $=($ Maximum - Minimum $) / \mathrm{n}=(5-1) / 5=0.8$. The average score is reduced to an interval scale.

Table 1. Scales of agreement based on points

\begin{tabular}{ccccc}
\hline $1.00-1.80$ (points) & $1.81-2.60$ (points) & $2.61-3.40$ (points) & $3.41-4.20$ (points) & $4.21-5.00$ (points) \\
\hline Totally disagree & Disagree & Quite agree & Agree & Strongly agree \\
\hline
\end{tabular}

The total number of questionnaires issued, collected and validated was 120, of which: 31 respondents are male (25.8\%) and 89 female (74.2\%). Of the 120 participants, 44 are management officers and 76 are lecturers and staff. In terms of working experience: 24 participants have from 1 to 3 years of experience (accounting for 20\%); From 3 to nearly 5 years: 33 people (accounting for $27.5 \%$ ); From 5 to 10 years: 40 people (accounting for 33.3\%); From 10 to 20 years: 23 people (accounting for 19.2\%).

Table 2. Reliability of the study

\begin{tabular}{clc}
\hline Code & \multicolumn{1}{c}{ Content } & $\begin{array}{c}\text { Planning resource development strategies } \\
\text { Cronbach's } \\
\text { Alpha }\end{array}$ \\
\hline HD1.1 & Planning and organizing the implementation of the university development strategy & 0.896 \\
\hline HD1.2 & $\begin{array}{l}\text { Planning and implementing strategies related to areas such as: Program development, } \\
\text { teaching plans; enrollment, etc. }\end{array}$ & 0.861 \\
\hline HD1.3 & $\begin{array}{l}\text { Planning income sources from training activities of educational levels, scientific } \\
\text { research, etc. }\end{array}$ & 0.884 \\
\hline HD1.4 & Planning strategies to develop teaching staff & 0.863 \\
\hline CC2.1 & \multicolumn{1}{c}{ Policy mechanism governance } & 0.858 \\
\hline CC2.2 & $\begin{array}{l}\text { Developing a mechanism to ensure that the University Council is the highest authority } \\
\text { in the university }\end{array}$ & 0.88 \\
\hline CC2.3 & $\begin{array}{l}\text { Associating the activities of the University Council with the exercise of autonomy } \\
\text { and social responsibility of the university }\end{array}$ & 0.831 \\
\hline CC2.4 & $\begin{array}{l}\text { Determining the content, form, accountability mechanism and evaluating the level of } \\
\text { accountability of the university }\end{array}$ & 0.842 \\
\hline & \multicolumn{1}{c}{ Organizing resource development } & 0.837 \\
\hline TC3.1 & $\begin{array}{l}\text { Decentralizing and exercising power among the trio of Party Committee, University } \\
\text { Council and Management Board }\end{array}$ & 0.874 \\
\hline TC3.2 & $\begin{array}{l}\text { Clearly defining tasks and powers of units and organizations in the school } \\
\text { TC3.3 }\end{array}$ & $\begin{array}{l}\text { Developing a coordination mechanism between the Party Committee, the University } \\
\text { Council, the Management Board and other units and organizations in the school }\end{array}$ \\
\hline TC3.4 & $\begin{array}{l}\text { Restructuring the management system in the direction of streamlining, compactness } \\
\text { and professionalism and assigning autonomy to faculties and institutes... }\end{array}$ & 0.816 \\
\hline
\end{tabular}




\begin{tabular}{clc}
\hline \multicolumn{1}{c}{ Orienting resource development } & 0.890 \\
\hline LD4.1 & Manage the resources appropriately and providing an effective support system & 0.860 \\
\hline LD4.2 & Raising people's awareness of the university's development goals and strategies & 0.847 \\
\hline LD4.3 & $\begin{array}{l}\text { Building a strict and feasible legal framework binding the self-responsibility of the } \\
\text { university's head }\end{array}$ & 0.856 \\
\hline LD4.4 & $\begin{array}{l}\text { Researching to improve the quality management organization system of teaching and } \\
\text { learning of both teachers and students }\end{array}$ & 0.870 \\
\hline \multicolumn{1}{c}{ Checking and monitoring activities } & 0.899 \\
\hline KT5.1 & $\begin{array}{l}\text { Checking and evaluating the structure of the education system to ensure the balance, } \\
\text { appropriateness and harmony in enrollment compared to the needs of society }\end{array}$ & 0.860 \\
\hline KT5.2 & $\begin{array}{l}\text { Checking and monitoring educational governance activities of the university under } \\
\text { the socialist-oriented market institution }\end{array}$ & 0.878 \\
\hline KT5.3 & Promoting checking and monitoring educational program innovation & 0.870 \\
\hline KT5.4 & $\begin{array}{l}\text { Promoting checking and monitoring universities' economic conditions on the basis } \\
\text { of studying the effectiveness of investment in education }\end{array}$ & 0.869 \\
\hline
\end{tabular}

Cronbach's Alpha reliability is 0.971 with a total of 20 items related to 5 sections, which evidences the survey's strong reliability. The results of Table 2 show that the reliability of each researched content has a reliability of $>0.810$, so the scale built has good reliability.

\section{RESULTS AND DISCUSSION}

The researchers would propose 5 components related to university governance in the context of educational innovation, including: (1) Planning resource development strategies; (2) Governance of policy mechanisms; (3) Organizing resource development; (4) Orienting resource development; (5) Checking and monitoring activities.

\subsection{Planning resource development strategies}

Planning strategies to develop resources in the governance, such as planning and implementing university development strategies (HD 1.1); Planning and implementing strategies related to areas such as: developing curriculum, teaching plans; recruiting students (HD 1.2); planning revenues of training activities from educational levels and scientific research (HD 1.3); planning lecturer development strategies (HD 1.4).

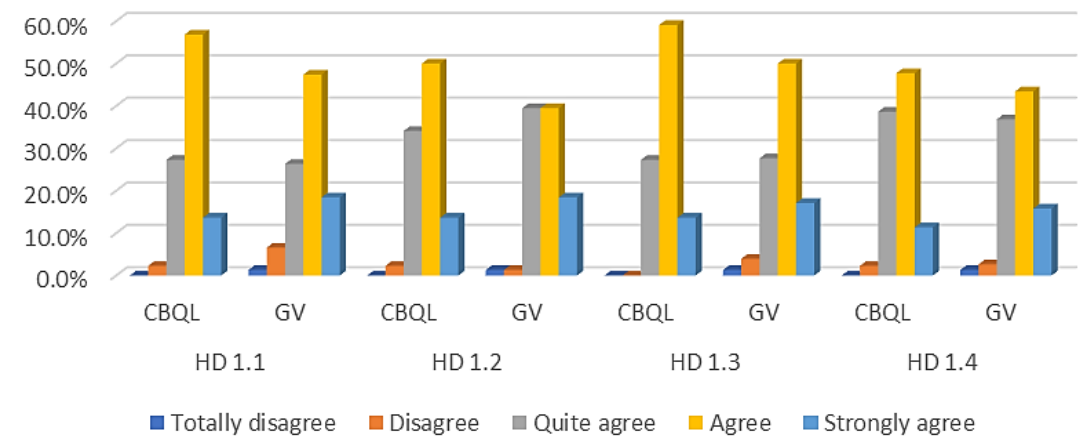

Figure 3. Planning resource development strategies in the context of educational innovation

The result of Figure 3 shows that more than $90 \%$ of the respondents agreed that 4 planning functions are necessary for university governance. A university is a place where teaching, researching and training activities occur. All the activities of training institutions aim to train human resources for the country, so educational institutions need to implement planning resource development strategies satisfying the following requirements:

+ Planning and implementing the strategic development of the university for management staff (with the average value of 3.818 points) and lecturers (with the average value of 3.750 points) are the level "Agree" and the deviation is 0.814 points.

+ Planning and implementing strategies related to areas such as: developing curriculum, teaching plans; recruiting students for management officers (with the average value of 3.760 points) and lecturers (with the average value of 3.724 points) are at the level "Agree" and the average deviation is 0.786 points. 
+ Planning revenues of training activities from educational levels, scientific research... for management officers (with the average value of 3.864 points) and lecturers (with the average value is 3.776 points) are at the level "Agree" and the average deviation is 0.788 points.

+ Planning lecturer development strategies for management officers (with the average value of 3.682 points) and lecturers (with the average value of 3.697 points) are at the level "Agree" and the average deviation is 0.776 points.

The results obtained show that both management officers and lecturers agreed about the 4 contents which need planning in the process of university governance. What should be taken in consideration is to crucially define goals and decide how to achieve them during the planning process. A well-designed plan will help the training institution to facilitate the success of managers by analyzing and predicting opportunities, challenges, difficulties and advantages in the process of achieving goals. The above plans, when proposed, must be accompanied by solutions to upgrading efficiency and minimizing risks.

\subsection{Policy mechanism governance}

Policy mechanism governance includes 4 specific contents: Separating governance activities from management activities (CC 2.1); Building a mechanism to ensure that university Council is the highest authority (CC 2.2); Associating the activities of the university Council with the exercise of the university's autonomy and social responsibility (CC 2.3) and determining content, form, accountability mechanism and evaluating the level of the university's accountability (CC 2.4).

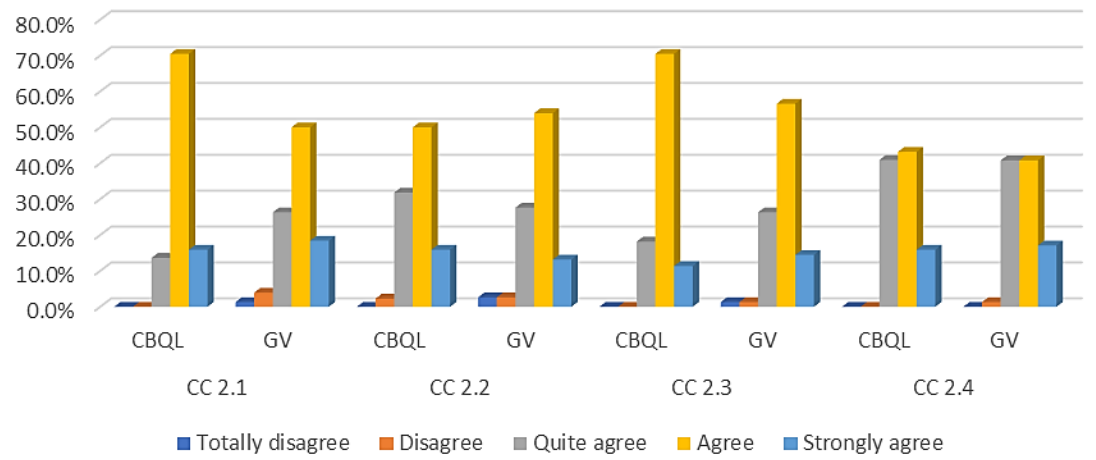

Figure 4. Policy mechanism governance for resource development in the context of educational innovation

The result of Figure 4 shows that over $85 \%$ of management officers and lecturers agreed on the policy mechanism of governance. The development of preferential policies for university lecturers and a good governance mechanism for improving competencies of educational management officers, especially the teaching staff, will create a motivation for them to perform the task to the best of their ability. Therefore, educational institutions need to implement policy mechanism governance meeting the following requirements:

+ Separating governance activities from management activities for management officers (with the average values of 4.023 points) and lecturers (with the average value of 3.803 points) are at the level of "Agree" and the average deviation is 0.747 points.

+ Developing mechanism to ensure that the University Council is the highest competent authority in the university for management officers (with the average value is 3.795 points) and lecturers (with the average value of 3.724 points) are at the level "Agree" with the average deviation is 0.791 points.

+ Associating university council's activities with the implementation of the autonomy and social responsibility of the university for management officers (with the average value of 3.932 points) and lecturers (with the average value of 3.816 points) are at the level "Agree" with the average deviation is 0.677 points.

+ Determining content, form, accountability mechanism and assessing the university's level of accountability for management officers (with the average value of 3.750 points) and lecturers (with the average value of 3.724 points) are at the level "Agree" with the average deviation is 0.764 points.

In addition, when policy mechanism governance is carried out, it is necessary to ensure adequate salary for lecturers so that they can concentrate on their professional jobs. However, the current budget is still insufficient to meet the requirements, especially the satisfactory salary for scientists to fully devote themselves to the assigned tasks. In order to solve the budget-related problems, training institutions need to have a governance mechanism to promote funding resources from Science and Technology programs of the State, from cooperation with enterprises, with local 
communities, with international partners. The policy mechanism administration needs governance and executive of the government. The governance mechanism needs to focus on the responsibilities of individuals or organizations. This is a governing measure to connect components with other areas of priority in training and research.

\subsection{Organizing resource development}

To organize the development of resources, our study proposes four specific contents: Decentralizing and exercising power among the trio of Party Committees, the University Council and the Director Board (TC 3.1); Clearly defining the tasks and powers of units and organizations in the university (TC 3.2); Developing a coordination mechanism between the Party Committee, the University Council, the Director Board and other units and organizations in the university (TC 3.3) and Restructuring the management mechanism in a streamlined, professional manner, and granting autonomy to faculties and institutes (TC 3.4).

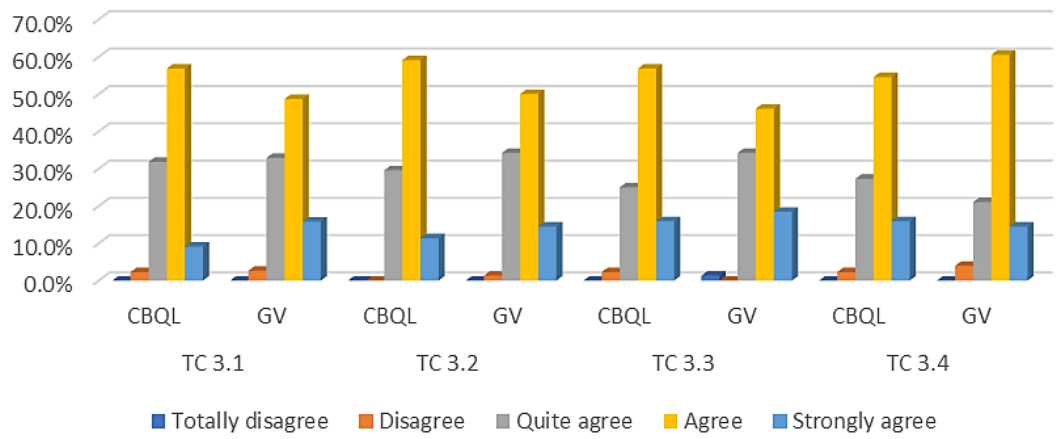

Figure 5. Organizing resource development in the context of educational innovation

The results of Figure 5 show that over $90 \%$ of surveyed management officers and lecturers agreed on the organization of resource development.

+ Decentralizing and exercising power between Party committees, University Council and Director Board for management officers (with the average value of 3.727 points) and lecturers (with the average value of 3.776 points) are at the level "Agree" with the average deviation is 0.710 points.

+ Specifying the tasks and powers of the units and organizations in the university for management officers (with the average value of 3.818 points) and lecturers (with the average value of 3.776 points) are at the level "Agree" with the average deviation is 0.672 points.

+ Constructing coordination mechanism between the Party Committee and University Council, Director Board and the units in the university for management officers (with the average value of 3.864 points) and lecturers (with the average value of 3.803 points) are at the level "Agree" with the average deviation is 0.752 points.

+ Restructuring the management mechanism in a streamlined, professional manner and Assigning autonomy to faculties and institutes for management officers (with the average value of 3.841 points) and lecturers (with the average value of 3.855 points) are at the level "Agree" with the average deviation is 0.706 points.

In response to the current regulations, a number of higher education institutions have established university councils, but it is still an act of formality. The role and functions of the University Council are unclear and incomplete. The responsibilities of the university council is not asserted in the organizational structure of most of the universities. The relationship between the Party Committee, the Director Board and University Council is not clearly defined. Therefore, in order to have efficient autonomy, a university must improve its university Council's responsibilities and powers. In order to increase the autonomy and responsibility in the training organization, the organizational governance of the University Council needs to continue to improve itself, and at the same time, there needs to be a reasonable division and decentralization between the Boards and Council.

\subsection{Orienting resource development}

Orienting resource development includes the following content: Manage the resources appropriately and providing an effective support system (LD 4.1); Motivating people to implement objectives and development strategies (LD 4.2); Building a clear and feasible leeway that binds the responsibility of the university's head (LD 4.3); Researching and improving the organizational system to manage the quality of teaching and learning of both lecturers and students (LD 4.4). 


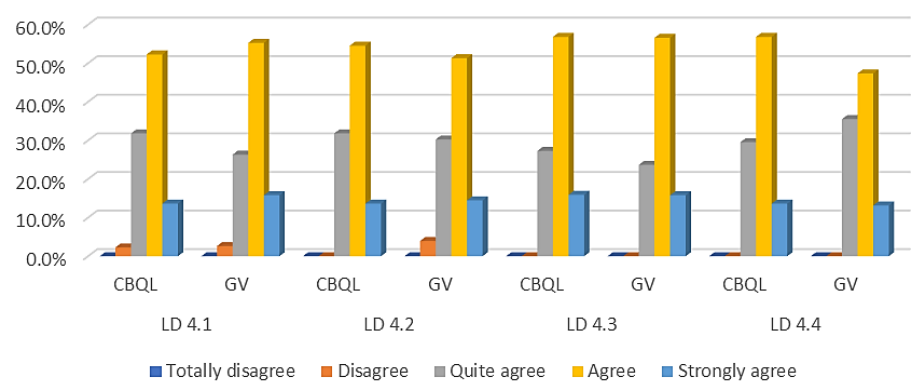

Figure 6. Manage and develop resources in the context of educational innovation

The results of Figure 6 show that over $90 \%$ of management officers and lecturers agree about leading resource development.

+ Leading right resource and providing an effective support system for management officers (with the average value of 3.773 points) and lecturers (with the average value of 3.842 points) are at the level "Agree" with the average deviation is 0.710 points.

+ Motivating people to implement objectives and development strategies for management officers (with the average value of 3.818 points) and lecturers (with the average value of 3.763 points) are at the level "Agree" with the average deviation is 0.712 points.

+ Building a clear and feasible leeway that binds the responsibility of the university's head for management officers (with the average value of 3.886 points) and lecturers (with the average value of 3.842 points) are at the level "Agree" with the average deviation is 0.702 points.

+ Researching and improving the organizational system to manage the quality of teaching and learning of both lecturers and students for management officers (with the average value of 3.841 points) and lecturers (with average value average of 3.697 points) are at the level "Agree" with the average deviation is 0.713 points.

The above results show that both management officers and lecturers agreed that developing human resources in the context of educational innovation means motivating individuals to achieve the university's goals through individual responsibility. Higher education institutions have regarded higher education innovation and international integration as indispensable to determine the direction in which resource organization will be implemented, specifically: application-oriented or research-oriented. However, in any direction, leadership and organization are subject to the remuneration regime, operating regulations, improving the quality of the teaching staff, officials, employees, and supplementing the teaching staff with lecturers who have studied or done research abroad and have the ability to perform professional tasks well, all of which play a decisive role in the success or failure of the education system.

\subsection{Checking and monitoring activities}

Checking and monitoring activities include 4 specific contents: Checking and monitoring educational structure system: ensuring balance, consistency and harmony in student enrollment in relation with the needs of society (KT 5.1); Inspecting and supervising educational governance activities of the university according to the socialist-oriented market institution (KT 5.2); Strengthening the inspection and supervision of educational program innovation (KT 5.3); Strengthening supervision of the university's economic conditions on the basis of studying the effectiveness of investment in education (KT 5.4).

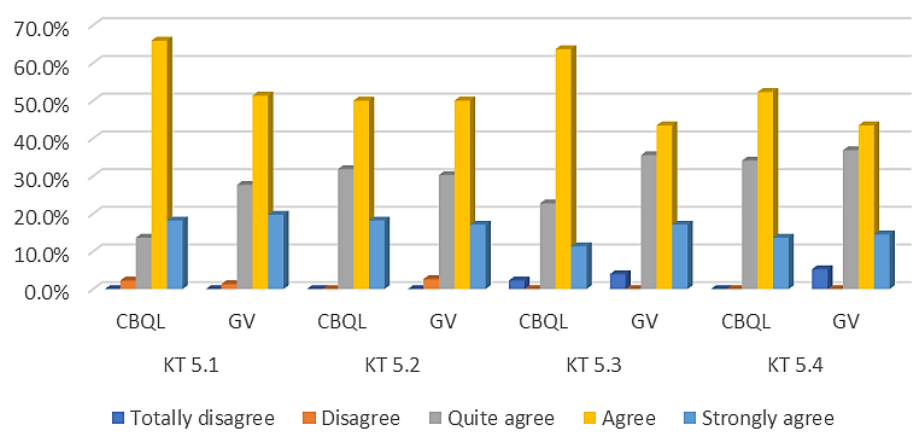

Figure 7. Checking and monitoring activities in the context of educational innovation 
The results of Figure 7 show that $100 \%$ of people agree about 4 contents related to checking and monitoring activities of university governance. When a training institution is granted autonomy, its tasks of checking and monitoring to perform will be:

+ Checking and monitoring educational structure system to ensure balance, consistency and harmony in student enrollment with social demands for management officers (with the average value of 4.00 points) and lecturers (with the average value of 3.895 points) are at the level "Agree" with the average deviation is 0.695 points.

+ Inspecting and supervising educational governance activities of the university according to the socialistoriented market institution for management officers (with the average value of 3.864 points) and lecturers (with the average value of 3.818 points) are at the level "Agree" with the average deviation is 0.726 points.

+ Strengthening the inspection and supervision of educational program innovation for management officers (with the average value of 3.841 points) and lecturers (with the average value of 3.737 points) are at the level "Agree" with the average deviation is 0.739 points.

+ Strengthening supervision of the university's economic conditions on the basis of studying the effectiveness of investment in education for management officers (with the average value of 3.795 points) and lecturers (with the average value of 3.671 points) are at the level "Agree" with the average deviation is 0.747 points.

Of ten management officers and lecturers interviewed, they all agreed on the necessary activities in university governance proposed, and they offered some complementary ideas for university governance:

University resource management is also reflected in the relationships between the subjects participating in the university's activities through decisions and policies. The university must maintain the potential (humans, materials) in all fields to ensure long-term development (Head of Unit - Male - age 48).

In order to improve the efficiency of university governance, the university needs to regularly cooperate with other educational institutions, local management agencies and the local community. Furthermore, training disciplines must be associated with social needs, are able to stable their inputs and the outputs are accepted by the social (Deputy Head of Unit - Female - age 40).

The primary concern in the autonomy mechanism is its own financial resources and other supporting financial resources to ensure salaries and other benefits for non-teaching staff and lecturers, which will create consensus when fully autonomous (Head of Unit - Male - age 44).

In order to implement governance well, the university needs to recruit a team of management officers at all levels (university, faculties, departments, service staff) with professional qualifications, appropriate management thinking, dedication, proactiveness and creativity in all aspects. In addition, the management staff of all levels must know how to rationally exploit the internal and external resources of the university to invest in university development activities (Deputy Head of Unit - Male - age 35).

Comparing the interview results with the questionnaire findings, we can see that the management officers and lecturers agreed on the need of strategic development planning, leading, organizing, checking and monitoring the activities related to teaching and training of the university. On the other hand, because the training activities of universities today are influenced by the laws of the market mechanism, especially the law of supply and demand, the law of value, universities meet not only the needs of human resources in the region, but the needs of all economic sectors of the national economy and everyone's learning needs as well.

\subsection{The relationship among university governance components}

Table 3. Relationship among university governance components (Pearson correlation)

\begin{tabular}{lccccc}
\hline & Hoachdinh & CocheCS & Tochuc & Lanhdao & Kiemtra \\
\hline Hoachdinh & 1 & $0.838^{* *}$ & $0.802^{* *}$ & $0.853^{* *}$ & $0.760^{* *}$ \\
\hline CocheCS & $0.838^{* *}$ & 1 & $0.836^{* *}$ & $0.890^{* *}$ & $0.836^{* *}$ \\
\hline Tochuc & $0.802^{* *}$ & $0.836^{* *}$ & 1 & $0.834 * *$ & $0.819^{* *}$ \\
\hline Lanhdao & $0.853^{* *}$ & $0.890^{* *}$ & $0.834 * *$ & 1 & $0.857 * *$ \\
\hline Kiemtra & $0.760 * *$ & $0.836 * *$ & $0.819 * *$ & $0.857 * *$ & 1 \\
\hline \multicolumn{7}{c}{ * Correlation is significant at the 0.01 level (2-tailed) }
\end{tabular}

After conducting descriptive statistical analysis, the study collected variables including:

+ Variable 1: Planning resource development strategies (Hoachdinh) includes 4 criteria coded from 1.1 to 1.4.

+ Variable 2: Policy mechanism governance (CocheCS) 4 criteria coded from 2.1 to 2.2. 
+ Variable 3: Organizing resource development (Tochuc) 4 criteria coded from 3.1 to 3.4 .

+ Variable 4: Leading resources development (Lanhdao) 4 criteria coded from 4.1 to 4.4 .

+ Variable 5: Checking and monitoring activities (Kiemtra) 4 criteria coded from 5.1 to 5.4.

With the results in Table 1, it can be seen that the correlation between the 5 groups in university governance > 0.76 i.e. $76.0 \%$ corresponds to the significance level of 0:01 i.e. $99 \%$ of reliability. The correlation between components in university governance is quite high, specifically:

+ Planning resource development strategies (Hoachdinh) has a high correlation with organizing resource development (Tochuc) (0.838 equals $83.8 \%$ ).

+ Planning resource development strategies (Hoachdinh) and leading resources development (Lanhdao) have a high correlation with 0.853 which equals $85.3 \%$.

+ Leading resources development (Lanhdao) and policy mechanism governance (CocheCS) have a high correlation with 0.890 equivalent to $89.0 \%$.

Therefore, we can conclude that the components related to university governance in the context of educational innovation proposed by the authors are fully appreciated by the management officers and lecturer staff of the university.

\section{CONCLUSION}

University governance brings about the success of a university. Transforming management into university governance will exercise crucial influence on improving the quality of higher education system's training. The university's management officers and lecturers are all well-aware of the issues related to university governance activities in the context of higher education innovation such as: Planning resource development strategies; Governance of policy mechanisms; Organizing resource development; Orienting resource development; Checking and monitoring activities. In addition, assessing the relationship among the components when operating university governance in the system-oriented approach shows the above elements are in an strong correlation between each other, namely: Planning resource development strategies has a high correlation with organizing resource development, leading resource development and governance of policy mechanisms bear a correlation to each other, which explains the fact that changing one component represents about 80 percent of the change of other ones. The results reveal that when governing university in the context of educational innovation, we must concentrate on the issues related to: (1) Planning and implementing resource development strategies, planning and implementing strategies related to areas such as: developing curriculum, planning teaching; enrollment; planning revenues from educational training, scientific research; planning development strategy of teaching workforce. Planning and organizing the implementation of long-term development strategies and annual development strategies of universities must be set high priority. And all plans must have social needs as the baseline start, current available and supplementary resources to ensure effective cost-recovery and university development; (2) Separating governance activities from management activities; developing a mechanism to ensure that the University Council is the highest authority; associating the university Council's activities with the exercise of autonomy and social responsibility of the university and determining the content, form, accountability mechanism and evaluating the level of accountability of the university; (3) Decentralizing and exercising power between the trio of Party Committees, the University Council and the Director Board; clearly defining the tasks and powers of units and organizations; developing a coordination mechanism between the Party Committee, the University Council, the Director Board and other units and organizations, and restructuring the management system in a streamlined, professional manner and granting autonomy for faculties and institutes; (4) Directing the adequate resources and providing an effective support system; raising people's awareness of the university's development goals and strategies; building a strict and feasible leeway binding the self-responsibility of the head of the university; researching to improve the organizational system of teaching and learning quality of both lecturers and students; (5) Checking and monitoring the structure of the education system: ensuring balance, suitability and harmony in enrollment in relation to social needs; inspecting and supervising educational administrative activities according to the socialist-oriented market institution; strengthening inspection and supervision of educational curriculum innovation; strengthening inspection and supervision of the economic conditions of the university on the basis of studying the effectiveness of investment in education.

Overall, regarding university governance activities in the context of educational innovation, apart from the governance of the above activities, we should pay attention to the renovation of higher education curriculum. International integration is one of the issues that should be taken account of in training institutions. The curriculum must adapt itself to the changing reality including constant socio-economic changes, and this requires human 
resources must change to adapt. That means the training program needs to have many optional subjects. In addition, leaders should manage teaching and learning activities well, harmoniously coordinate the teaching of lecturers and learning of students. It is necessary to correctly identify the teacher as the leading role in teaching activities, and the student as the learning subject. On this basis, we can determine the standard requirements as well as the appropriate remuneration policy for teachers and learners, create a healthy competition in both teaching and learning, help to improve the quality of education and satisfy the needs of society and learners.

Conflict of Interest: No potential conflict of interest relevant to this article was reported.

Funding: The authors received no financial support for this article.

\section{PREFERENCES}

Allan, A. (2012). Managing the process of new and creative change (Nguyen Hong, trd.). Hanoi: National Economics University Publishing House.

Cao, V. (2016). Solutions to increasing autonomy and social responsibility at universities in the current context of educational innovation. University autonomy and social responsibility. Hanoi: Information and Communication Publishing House.

Dinh, X. K. (2019). Governance of public university in the current context. The PhD thesis in the field of Educational Management, Vinh University, 20-40.

Do, T. V. (2014). System theory and application in information systems. Vietnam Library Journal, 5(18), 35-40.

Government of The Socialist Republic of Vietnam (2005). Resolution 14/2005/NQ-CP dated November 2, 2005 on the fundamental and comprehensive education innovation in Viet Nam in the period 2006-2020.

Kezar, A., \& Eckel, P. D. (2004). Meeting today's governance challenges: A synthesis of the literature and examination of a future agenda for scholar- ship. Journal of Higher Education, 7(4), 371-399.

Le, C. L. (2021). Proposing a university governance model towards university autonomy. Vietnam Journal of Educational Sciences, 39, 1-6.

Le, C. L., \& Do, D. T. (2019). Some university governance solutions approaching the trend of autonomy. Journal of Educational Management Science, 4(24), 43-50.

Ngo, T. M. (2012). Reforms of university governance to upgrade training quality: what Vietnam could learn from the world's realities. International Conference.

Nguyen, D. P., \& Nguyen, H. H. N. (2013). University governance and Vietnamese universities of Economy models. Journal of Development and Integration, 18, 1-6.

Pham, T. L. (2009). Building an effective university governance system - American experience. Report at the 53rd International and Comparative Education Conference in Carolina, USA.

Simon, M., \& Mark, C. (2000). The Enterprise University: Power, Governance and Reinvention in Australia. Cambridge University Press, 88-98.

The Central Committee of the Communist Party of Vietnam (2013). Resolution No. 29-NQ/TW dated November 4, 2013 on fundamental and comprehensive innovation in education, in response to industrialization and modernization in a socialist-oriented market economy during international integration.

The Politburo of the Central Committee of the Communist Party of Vietnam (2019). Resolution No. 52-NQ/TW dated September 27, 2019 on a number of guidelines and policies for active participation in the industrial revolution 4.0.

The Prime Minister of Vietnam (2017). Directive No.16/CT-TTg dated May 04, 2017 on promoting access to the Industrial Revolution 4.0.

Tran, N. C. (2018). Autonomy and social responsibility related to governance, finance for university education institutions in the context of current education innovation according to the Resolution 29-NQ/TW. Education conference 2018: University education - standardization and international integration, Culture, Education, Youth, Adolescence and Children Committee of National Assembly. 